\title{
PHENOLIC COMPOUNDS, CAROTENOIDS, TOCOPHEROLS AND FATTY ACIDS PRESENT IN OILS EXTRACTED FROM PALM FRUITS
}

MICHELLE CARDOSO COIMBRA*

NEUZA JORGE**

\begin{abstract}
This review aimed to discuss the main bioactive compounds present in oils extracted from palm trees, indicating possible applications for the same. The bioactive compounds approached were: phenolic compounds, carotenoids, tocopherols, mono and polyunsaturated fatty acids. It is growing the search for food, especially from plant origin, characterized by the presence of such substances due to their benefits. Many studies show palm species as important sources of bioactive compounds and essential fatty acids. Therefore it is important to study the fruit characterization and composition of the oil from palm species of different regions that are still poorly investigated, seeking the possibility of its application in industry or the development of functional foods.
\end{abstract}

* Biotecnologista, Mestre em Ciência e Tecnologia de Alimentos pela Universidade Estadual Paulista (UNESP), São José do Rio Preto, SP (e-mail: mi_ccoimbra@yahoo.com.br).

** Engenheira de Alimentos, Mestre em Engenharia Agrícola, Doutora em Engenharia de Alimentos, Livredocente em Tecnologia de Óleos e Gorduras, Professora Adjunta, UNESP, São José do Rio Preto, SP (e-mail: njorge@ibilce.unesp.br). 


\section{INTRODUCTION}

Functional foods contain bioactive compounds that may promote benefits to the body reducing the risk of disease and helping to maintain health. Examples of these bioactive compounds are phenolic compounds, carotenoids and tocopherols, which have potent antioxidant activity, retarding or preventing the action of free radicals in the body (WALZEM, 2004).

The unsaturated fatty acids contained in food, especially the essential fatty acids, also exerts a positive effect over the body acting on the control of blood cholesterol and preventing heart diseases (LIRA et al., 2004). Foods of plant origin are one of the main sources of biologically active compounds and polyunsaturated fatty acids, what has motivated many studies in an attempt to find plant species that are rich in such compounds. Among these species, the palm trees are worth mentioning and have being the focus of many studies to elucidate the composition of fruits and oils extracted from these plants. Palm trees have been shown as promising sources of bioactive compounds; many studies show the antioxidant potential of the fruits and fatty acid composition of the oil extracted from the pulps and kernels of several species (CLEMENT, LLERAS and VANLEEUWEN, 2005).

The aim of this work was to show different studies pointing that palm trees are rich sources of bioactive compounds, and elucidate the importance and protective action of such compounds in humans.

\section{FUNCTIONAL FOODS}

Besides nourishing, food has active components that act in the body, producing beneficial health effects (PRATES and MATEUS, 2002). The study of these active components led to the concept of functional foods. The functional food concept was first developed in Japan in the late 1980 s and refers to foods that are similar in appearance to conventional foods, but have physiological benefits that contribute and/or reduce the risk of chronic disease beyond basic nutritional functions. Regular consumption of functional foods could potentially reduce the chances of certain cancers, heart disease, osteoporosis, intestinal problems and many other health conditions (BRANDÃO, 2002). Thus, functional foods come from the opportunity to combine high flexibility edible products with biologically active molecules, as a strategy to consistently correct metabolic disorders, resulting in reduced risks of diseases and health maintenance (WALZEM, 2004).

Functional foods are one of the priorities of research worldwide in order to elucidate the properties and effects that these products may have on health promotion (OLIVEIRA et al., 2002).

Kruger and Mann (2003) have defined functional ingredients as a group of compounds that offer health benefits, such as polyunsaturated fatty acids, allicin, vitamins, antioxidants (such as tocopherols and carotenoids), glucosinolates, phenolic compounds and nitrogen compounds. These biologically active compounds can be found in many vegetables and oils extracted from their pulp and kernel.

\section{BIOACTIVE COMPOUNDS AND ANTIOXIDANT ACTIVITY}

Bioactive compounds such as phenolic, tocopherols and carotenoids have potent antioxidant property, acting as substances that retard or prevent the effects of free radicals in the body. Free radicals are known as the organic and inorganic molecules that contain one or more unpaired electrons. This configuration makes free radicals highly unstable molecules with very short half-life and very chemically reactive (HALLIWELL, 1994).

In the body, the presence of free radicals is critical to the maintenance of many physiological functions (POMPELLA, 1997). Among the species of free radicals are: singlet oxygen $\left({ }^{1} \mathrm{O}_{2}\right)$, superoxide radical $\left(\mathrm{O}_{2} \bullet\right.$ ), hydroxyl $(\mathrm{OH} \bullet)$, nitric oxide $(\mathrm{NO} \bullet)$, peroxynitrite $(\mathrm{ONOO} \bullet)$ and semiquinone 
$(Q \bullet)$. Free radicals can be generated in the cytoplasm, mitochondria or in the membrane during electron transfer processes that occur in cellular metabolism and by exposure to exogenous factors, such as ozone, ultraviolet and gamma rays, medications, diet and smoking (YU and ANDERSON, 1997).

The imbalance between free radicals (oxidants molecules) and antioxidants results in the induction of damage and cell death (ANDERSON, 1996). The oxidative damage induced in cells and tissues have been linked with several diseases, including degenerative diseases such as heart conditions, atherosclerosis, lung problems, arthritis, brain dysfunction, diabetes, cataracts, aging, multiple sclerosis, cancer, chronic inflammation and diseases of the immune system (STAHL and SIES, 1997).

Oxidative stress has also been a major factor in the pathophysiology of metabolic syndrome. There is evidence that increased free radical production is inversely correlated to insulin action. Metabolic syndrome is a cardiovascular risk factor, characterized by the association of hypertension, abdominal obesity, impaired glucose tolerance, hypertriglyceridemia and low blood concentrations of HDL. An adequate diet, with foods rich in antioxidants, combined with other changes in lifestyle, such as regular physical activity and smoking cessation, contribute to a better control of disease, preventing complications and improving quality of life (FORD et al., 2003).

Basically, antioxidants from a natural diet strengthen the defense system naturally present in the body, reducing oxidative stress and risk of chronic diseases caused by free radicals (HUI et al., 2006). Phenolic compounds, carotenoids and tocopherols have antioxidant activity, functioning as defense mechanisms, being responsible for inhibition and reduction of injuries caused by free radicals in cells.

\subsection{PHENOLIC COMPOUNDS}

Phenolic compounds from plant sources can be divided into two groups: flavonoids and non-flavonoids, both of which are secondary metabolites present in fruits and vegetables. Flavonoids chemical structure is described as $\mathrm{C}_{6}-\mathrm{C}_{3}-\mathrm{C}_{6}$ (Figure 1 ). The non-flavonoids have chemical structure $\mathrm{C}_{1}-\mathrm{C}_{6}$ (gallic acid and ellagic acid), $\mathrm{C}_{6}-\mathrm{C}_{3}$ (caffeic acid) or $\mathrm{C}_{6}-\mathrm{C}_{2}-\mathrm{C}_{6}$ (resveratrol). The most studied phenolic compounds are: caffeic acid, gallic acid, ellagic acid, resveratrol and anthocyanins (MELO and GUERRA, 2002).

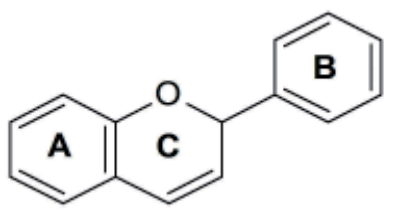

\section{FIGURE 1 - CHEMICAL STRUCTURE OF FLAVONOID COMPOUNDS}

Source: MELO and GUERRA, 2002.

The distribution of flavonoids in plants depends on several factors according to phylum, order and family of the plant, as well as the variation of species. Flavonoids are formed from the combination of synthesized derivatives of phenylalanine and acetic acid. The distribution pattern depends on the degree of access to sunlight, especially ultraviolet rays, because the formation of flavonoids is accelerated by light (AHERNE and O'BRIEN, 2002).

The determination of phenolic compounds levels in plant tissues is the initial step of any investigation of physiological functionality for further stimulus to consumption for the prevention of chronic degenerative diseases (ANTOLOVICH, PRENZLER and RYAN, 2000).

Among the phenolic compounds frequently found in plants are anthocyanins, flavonols, catechins and tannins. Many of these compounds have a wide range of biological effects such as 
antioxidant, antimicrobial, antiinflammatory, antiplatelet and vasodilatory actions. They can inhibit enzymes, especially prostaglandin synthetase, lipoxygenase and cyclooxygenase, all directly related to tumorigenesis. They can also induce enzymes of the detoxification system like the glutathione transferase (AHERNE and O'BRIEN, 2002).

The renowned antioxidant properties of flavonoids makes these compounds capable of inhibiting lipid peroxidation and oxidation of low density lipoproteins (LDL), and significantly reduce the tendency to thrombotic diseases. Epidemiological studies show that some phenolic compounds are associated with protection against aging diseases and prevention of cancer, cardiovascular and neurological diseases, which can also be explained by its antioxidant action (RAUHA et al., 2000).

The antioxidant activity of phenolic compounds is mainly due to their redox properties, which may play an important role in absorbing and neutralizing free radicals, triplet and singlet oxygen or decomposing peroxides (ZHENG and WANG, 2001).

\subsection{CAROTENOIDS}

The carotenoids are among the pigments most commonly found in nature with an estimated production of 100 million t per year. They have been identified in photosynthetic organisms and nonphotosynthetic, plants, algae, fungi, bacteria and some animals. They are responsible for the colors from yellow to red of fruit, vegetables, fungi and flowers (MALDONADO-ROBLEDO et al., 2003).

The basic structure of carotenoids is a tetraterpene $\left(\mathrm{C}_{40}\right)$ consisting of eight isoprenoid units $\left(\mathrm{C}_{5} \mathrm{H}_{8}\right)$ joined by "head-tail" links, with the exception of the central location where the link is "tail-tail". Of the more than 600 carotenoids now known, about 50 are precursors of vitamin A. The carotenoid precursor has at least one $\beta$-ionone ring not substituted, with polyene side-chain with a minimum of 11 carbons. The main pro-vitamin A carotenoids are $\beta$-carotene, $\alpha$-carotene, $\gamma$-carotene and $\beta$-cryptoxanthin; among the non pro-vitamin are lutein, zeaxanthin and lycopene. The $\beta$-carotene is the most abundant in foods and has the highest activity of vitamin $A$ ( $100 \%$ activity), while $\gamma$-carotene, $\alpha$-carotene, $\beta$-zeacarotene, $\beta$-cryptoxanthin and $\alpha$-cryptoxanthin have only $50 \%$ activity (RODRIGUES-AMAYA, KIMURA \& AMAYA-FARAFAN, 2008).

The processing of pro-vitamin carotenoids into vitamin A occurs by a symmetric cleavage (primary mechanism), where the carotenoid is divided in half, forming two molecules of retinol in the case of $\beta$-carotene or just one molecule in the case of others pro-vitamin A carotenoids which are then converted into retinol. Alternatively, asymmetric cleavage can occur in segments that are removed from one extremity of the carotenoid molecule, forming apocarotenoids and eventually retinal, as shown in Figure 2 (AMBRÓSIO, CAMPOS and FARO, 2006).

The insufficient intake of vitamin $A$ or its precursors, during a significant time, leads to blindness and has resulted in high mortality rates (60\%), mainly in children (RODRIGUEZ-AMAYA, 2004). Population at risk of vitamin A deficiency, in general, depend on pro-vitamin A carotenoids to achieve the daily recommendations listed for this vitamin. The ingestion of pro-vitamin $A$ has the advantage of being the only bioconverted by the body when there is shortage, avoiding toxic (ROCK et al., 1998).

Among the main strategies used to combat vitamin A deficiency in developing countries are supplementation, food fortification and dietary changes, including increased consumption of vegetables rich in carotenoids (CAMPOS and ROSADO, 2005).

In addition to vitamin A active, other biological functions have been related to carotenoids, including those no pro-vitamin. These compounds are recognized for their antioxidant activity through deactivation of free radicals and mainly abduction of singlet oxygen. Carotenoids "kidnap" singlet oxygen in two ways: by physical transfer of excitation energy of singlet oxygen to the carotenoid or through a chemical reaction of the carotenoid with singlet oxygen. Under normal conditions in the body, for example, $95 \%$ of the singlet oxygen deactivation occurs physically, leaving only $5 \%$ to chemically react, which makes the antioxidant carotenoids most effective (BARREIROS, DAVID and DAVID, 2006). 


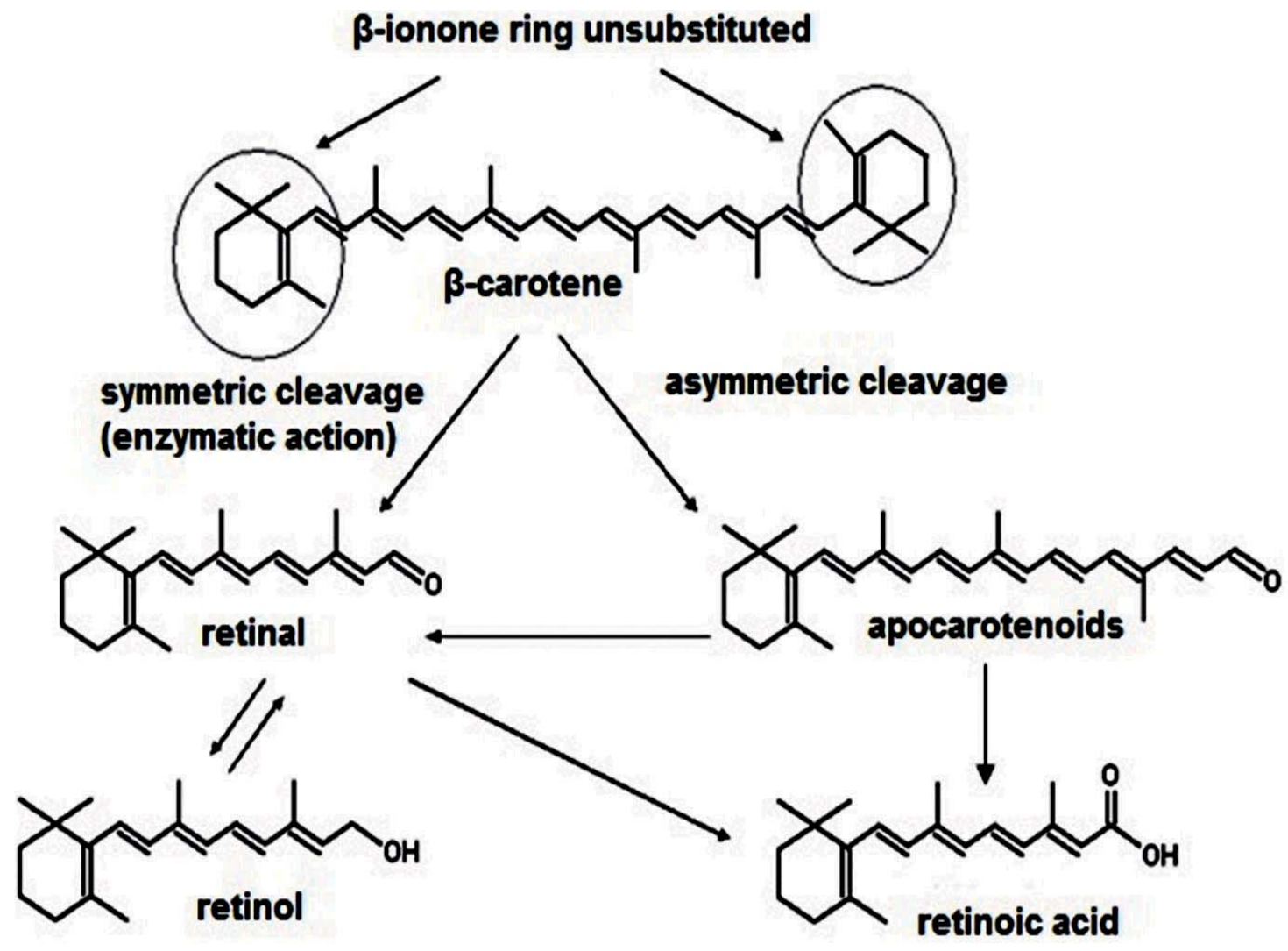

FIGURE 2 - TRANSFORMATION OF $\beta$-CAROTENE INTO VITAMIN A

Source: AMBRÓSIO, CAMPOS and FARO, 2006.

Thus, these compounds may act in the modulation of carcinogen metabolism, increased immune response, inhibition of cell proliferation, increased intercellular communication channels, which appear to stabilize the initiated cells, those are cells with altered genetic material that can result in mutation and thus prevent malignant cell transformation (TROSKO and CHANG, 2001).

Furthermore, carotenoids are able to assist in the protection of various degenerative diseases such as cancer, macular degeneration, cataracts, cardiovascular diseases and disorders of photosensitivity. The oxidation of LDL-cholesterol is crucial for the development of atherosclerosis and $\beta$-carotene acts by inhibiting the oxidation of this lipoprotein (AMBRÓSIO, CAMPOS and FARO, 2006).

\subsection{TOCOPHEROLS}

The term vitamin $\mathrm{E}$ is considered as a generic name describing the bioactivities of tocopherols and tocotrienols derivatives, fat-soluble vitamins that have high antioxidant capacity, specifically against lipid peroxidation in biological membranes (ALMEIDA et al., 2006).

Natural Vitamin $E$ is composed of eight different substances that belong to two groups of compounds. The first group derives from tocol and has a saturated side chain containing 16 carbon atoms. This group includes four of the eight compounds: $\alpha$-tocopherol, $\beta$-tocopherol, $\gamma$-tocopherol and $\delta$-tocopherol. The difference between these molecules is the amount of methyl groups substituting the aromatic ring of the tocol (HOPE and KRENNRICH, 2000), as shown in Figure 3.

The second group of substances with biological activity of Vitamin $E$ is derived from the tocotrienol. This group includes the remaining four molecules that make up the Vitamin $\mathrm{E}$ : $\alpha$-tocotrienol, $\beta$-tocotrienol, $\gamma$-tocotrienol and $\delta$-tocotrienol. The difference between these molecules and their counterparts is the fact that they have an unsaturated side chain containing 16 carbon 
atoms. As the isomers of tocopherol, the difference among the various position isomers $(\alpha, \beta, \gamma, \delta)$ is only the fact that substitution of methyl groups are made at different sites of the aromatic ring (HOPE and KRENNRICH, 2000) as shown in Figure 3.<smiles>[R]c1c([R])c2c(c([R])c1O)CCC([R])(C)O2</smiles>

Where:

$\alpha$ - toco: $R_{1}=R_{2}=R_{3}=\mathrm{CH}_{3}$

$\beta$ - toco: $\mathrm{R}_{1}=\mathrm{R}_{3}=\mathrm{CH}_{3} ; \mathrm{R}_{2}=\mathrm{H}$

$y$ - toco: $\mathrm{R}_{2}=\mathrm{R}_{3}=\mathrm{CH}_{3} ; \mathrm{R}_{\mathbf{1}}=\mathrm{H}$

$\delta$ - toco: $\mathrm{R}_{1}=\mathrm{R}_{2}=\mathrm{H} ; \mathrm{R}_{3}=\mathrm{CH}_{3}$<smiles>[R]CCCC(C)CCCC(C)CCCC(C)C</smiles><smiles>[R]CC/C=C(/C)CC/C=C(\C)CCC=C(C)C</smiles>

\section{FIGURE 3 - CHEMICAL STRUCTURE OF TOCOPHEROL AND TOCOTRIENOL}

Source: HOPE and KRENNRICH, 2000.

Vitamin $E$ in the form of a-tocopherol is found in large amounts in lipids and evidence suggests that this compound prevents or minimizes damage caused by free radicals associated with specific diseases, including cancer, arthritis, cataracts and aging (HEINONEN et al., 1998). The a-tocopherol has the ability to prevent the spread of chain reactions induced by free radicals in biological membranes; the antioxidant activity is mainly due to its ability to donate hydrogen to free radicals, thereby inhibiting oxidative action of these compounds (TRABER, 1997).

Several epidemiological studies and clinical trials indicate that a high intake or high plasma levels of vitamin $\mathrm{E}$ are associated with reduced risk of cardiovascular disease, improve immune system, modulate important degenerative conditions associated with aging, protect the eye, skin, liver, breast, testis tissues and central nervous system that are more sensitive to oxidation, reduces the risk of thrombosis by inhibiting platelet aggregation and adhesiveness (SOUZA, SOUZA NETO and MAIA, 2003). Experiments with animals show that tocotrienols can inhibit the enzyme HMGCoA reductase, which acts in the synthesis of cholesterol (KHOR, CHIENG and ONG, 1995).

\section{FATTY ACIDS}

Besides the content of bioactive compounds, the fatty acid composition of vegetable oils is also of great importance, especially the polyunsaturated omega- 3 and omega- 6 , to which are attributed numerous benefits to the human body, such as lowering blood cholesterol. The omega- 3 $(\omega-3$ or $n-3)$ includes the essential fatty acid $\alpha$-linolenic, whereas the omega-6 ( $\omega-6$ or $n-6)$ includes the essential fatty acid linoleic (LIRA et al., 2004).

The $\alpha$-linolenic and linoleic acids are essential fatty acids because their double bonds located on the third and sixth carbon atoms can not be produced by the human body, so these fatty acids must be obtained from the diet. In the body, linolenic acid can be elongated and desaturated by the enzyme system to produce docosahexaenoic and eicosapentaenoic, likewise, linoleic acid is the precursor of arachidonic acid (CONNOR, 2000).

Linoleic acid can be found in abundance in corn, sunflower and soybean oils, among other vegetable oils. While $\alpha$-linolenic acid is found in high concentrations in flaxseed (Linum usitatissimum), 
which presents content ranging from 44.6 to $51.5 \%$ of total fatty acids (CARTER, 1993).

Among the main functions of these fatty acids are the energy storage and shape of cell membranes; also are precursors of a group of substances called eicosanoids, which have physiological and pharmacological activities. These substances include the thromboxanes and prostaglandins, which possess hypotensive effects; the prostacyclin, which inhibit platelet aggregation and increase HDL cholesterol, and leukotrienes. The balance between the production of prostaglandins and thromboxanes inhibits the onset of cardiovascular disease (TURATTI, GOMES and ATHIÉ, 2002).

The omega- 3 and omega- 6 have been the focus of many epidemiological studies because they reduce the triglyceride levels, improve platelet function, further reduction in blood pressure, cholesterol and low density lipoproteins levels in the blood, as well as prevent some types of cancer (AHA, 2001).

The main monounsaturated fatty acid is the oleic acid (C18:1) which belongs to the omega-9 ( $\omega-9$ or $n-9)$, because the double bond is located between carbons 9 and 10 . Studies show that oleic acid has a neutral effect on cholesterol, however, it has been observed that diets rich in oleic acid increase HDL-cholesterol and can reduce levels of LDL-cholesterol. These fatty acids are also associated with the reduction of heart disease incidence (MAHAN and ESCOTT-STUMP, 2002).

\section{TROPICAL PALM TREES}

Plant foods are one of the main sources of biologically active compounds and polyunsaturated fatty acids, which have supported for many studies in attempt to find plant species rich in such compounds. Among these species, the palm trees are worth mentioning and constitute focus of studies to elucidate the composition of fruit and oil extracted from them.

The palms are the main symbol of tropical forests since many of the existing species occur exclusively in the tropics, representing one of the largest plant families, both in richness and in abundance, occupying almost every conceivable habitat. It is believed that there are 3500 species in 240 genera of palms around the world, being widely distributed in well-drained areas, but rare in very dry or cold ones. In the tropics, there are 550 species and 67 genera. In Brazil, there are 119 species distributed in 39 genera (DONATTI, 2004). These species had great importance in the livelihoods of indigenous peoples, some ones are still important in the livelihoods of people today, and some are economically important in the world market. Currently the potential of palm trees is again brought into focus, especially due to its application on the production of biodiesel (CLEMENT, LLERAS and VAN-LEEUWEN, 2005).

Most palm trees used as food by early people contain high quantities of starch, protein, vitamins and oil in different proportions. Some offer considerable amounts of palm oil in the fruit pulp (mesocarp), others in the nut, and some in both. About the mesocarp oil, this tends to be rich in the monounsaturated oleic acid (CLEMENT, LLERAS and VAN-LEEUWEN, 2005). These plants stand out in natural, economic and ecological terms. They are part of human nutrition in the form of fruit, palm and finished products, like candy, beverages and oils (PEREIRA, 1996).

Palm trees have been presented as promising sources of bioactive compounds, and many studies show the antioxidant potential of fruits and fatty acid composition of oil extracted from the pulp and kernel of several species.

In a study by Biglari, Alkarkhi and Easa (2008) were analyzed the antioxidant activity and phenolic compounds in fruits of date palm (Phoenix dactylifera). There were high levels of phenolic compounds, among which flavonoids were the most prominent. The results also indicated a strong correlation between antioxidant activity and contents of phenolics and flavonoids of the fruit.

Açaí is the fruit of the palm Euterpe oleracea. Studies show that this fruit is rich in phenolic compounds such as anthocyanins, whose presence is also directly related to antioxidant activity. According to Bobbio et al. (2000), the content of anthocyanins in the açaí is $50 \mathrm{mg}$ in $100 \mathrm{~g}$ of pulp and $263 \mathrm{mg}$ in $100 \mathrm{~g}$ of peel. 
Archontophoenix alexandrae seeds were analyzed for chemical composition and fatty acid profile of oil. The study found a high content of oleic (42\%) and linoleic acid (13\%) in the portion of unsaturated lipids. The content of $\alpha$-tocopherol in the oil was equivalent to $4.0 \mathrm{mg} / 100 \mathrm{~g}$, and $\delta$-tocopherol to $1.8 \mathrm{mg} / 100 \mathrm{~g}$, these values already result in oil with desirable oxidative stability (VALLILO et al., 2004).

The palm trees have also been identified as rich sources of carotenoids. Ramos et al. (2007) analyzed the composition of carotenoids in Acrocomia aculeata (macaúba or bocaiúva). The $\beta$-carotene content was $49 \mathrm{mg} / \mathrm{g}$, representing $82 \%$ of the total carotenoids. The other carotenoids in low concentration were identified as $\gamma$-carotene, $\beta$-cryptoxanthin, cis-lycopene and cis-flavoxanthin. The study also pointed that macaúba pulp is rich in unsaturated fatty acids such as oleic acid, which can influence the bioavailability of carotenoids. By comparison, other studies have found levels of $\beta$-carotene of $62 \mathrm{mg} / \mathrm{g}$ in carrots (NIIZU and RODRIGUEZ-AMAYA, 2005), $40 \mathrm{mg} / \mathrm{g}$ in melon (CASAGRANDE and KIMURA, 2006) and $57 \mathrm{mg} / \mathrm{g}$ in pumpkin (AZEVEDO-MELEIRO and RODRIGUEZ-AMAYA, 2005), values close to the levels of $\beta$-carotene found in macaúba.

The peach palm (Bactris gasipaes) is a tropical fruit that represents a potentially nutritious food source for its high content of bioavailable carotenoids. Andrade, Pantoja and Maeda (2003) identified the $\beta$-carotene as the major carotenoid in the fresh peach palm, with values of 24.60 and $47.10 \mathrm{mg} / \mathrm{g}$ in the fresh and baked fruit, respectively.

Bacuri (Scheelea phalerata Mart.) belongs to the Palmae family and is widely distributed in Mato Grosso do Sul and Mato Grosso (Brazil). The pulp has colors that range from yellow to orange by the presence of carotenoids. Hiane et al. (2003) analyzed the bacuri pulp for the presence of carotenoids and fatty acids profile. The results revealed a $\beta$-carotene content of $37.5 \mathrm{mg} / \mathrm{g}$ and $\beta$-zeacarotene of $11.68 \mathrm{mg} / \mathrm{g}$ of dry pulp. The pulp oil presented a high degree of unsaturation, and the main fatty acids were oleic acid $(52.90 \%)$ and linoleic $(11.80 \%)$, an essential fatty acid.

The buriti (Mauritia flexuosa), native from swampy areas throughout northern South America, has one of the highest concentrations of carotenoids. The analysis of the oil extracted from the buriti pulp revealed total carotenoids of $446 \mathrm{mg} / \mathrm{g}$, and $364 \mathrm{mg} / \mathrm{g}$ correspond to $\beta$-carotene (GODOY and RODRIGUEZ-AMAYA, 1995). The buriti pulp oil, besides the high content of carotenoids, has a very high amount of tocopherols, especially a-tocopherol and $\beta$-tocopherol. According to Chemyunion (2002), the concentration of total tocopherols in the buriti oil is $1956 \mathrm{mg} / \mathrm{kg}$, being a-tocopherol $1099 \mathrm{mg} / \mathrm{kg}$ and $\beta$-tocopherol $842 \mathrm{mg} / \mathrm{kg}$.

Bora et al. (2003) studied the composition of the oils from the pulp and seeds of palm fruits Eliaes guineensis. The pulp and seeds showed to be rich sources of lipids, with 73.2 and $32.6 \%$, respectively. The pulp oil presented a high percentage of monounsaturated and polyunsaturated fatty acids and oleic acid was predominant.

The cosmetics industry is also showing interest in the oil extracted from palm trees such as oleic-palmitic oil and lauric oil. Given the similarity of these oils with other ones, it is believed that the demand increases because they are Amazon species (Brazil), which is an extra attraction for consumers. Some species used for this purpose are the babassu (Attalea speciosa), buriti (Mauritia flexuosa), patauá (Oenocarpus bataua) and muru-muru (Astrocaryum murumuru) (CLEMENT, LLERAS and VAN-LEEUWEN, 2005).

\subsection{GUARIROBA PALM (Syagrus oleracea Becc)}

The guariroba, also known as gueiroba and gariroba is a palm tree distributed in the states of Minas Gerais, Goiás, Mato Grosso and São Paulo (Brazil), of bitter taste is very much appreciated (LORENZI, 2000). It is adapted to the conditions of intense sunlight and low rainfall, with water shortages in winter, which can also be used as an ornamental, particularly in urban forestry, due to its beauty and ease growth (BOVI, TONET and PELINSON, 2000). Its commercial exploitation has intensified with the advent of commercial plantations for fresh and industrial consumption 
(CARNEIRO, ROLIM and FERNANDES, 2003).

The guariroba palm tree has a straight trunk reaching a height of about $20 \mathrm{~m}$. The leaves are about $3 \mathrm{~m}$ and each cluster contains 10 to 40 fruit. The fruit is greenish-yellow, with a white edible oleaginous kernel. The kernel can be used to several homemade candy and edible oils greatly appreciated in regional cuisine. The kernel oil can also be used in the production of soaps, due to its high lipid content. The palm heart extracted from its stem is the main attraction of guariroba and can be used as an ingredient in many recipes. Because of these many uses and the fact that this palm is easy to grow, their planting becomes profitable (BORA and MOREIRA, 2003).

\subsection{JERIVÁ PALM (Syagrus romanzoffiana)}

The jerivá palm belongs to the Palmae family and it is also known as geriva, coqueirogeriva, coco-de-cachorro, baba-de-boi, coco-de-catarro, coco-de-babão and it is distributed in Brazil from the south of Bahia, Espírito Santo, Minas Gerais and São Paulo to Rio Grande do Sul and Mato Grosso do Sul (LORENZI, 2004).

The oval yellow fruit has only $3 \mathrm{~cm}$ in its widest part; they are about 100 units $/ \mathrm{kg}$, up to produce around $140 \mathrm{~kg}$. The outer part, fleshy, is composed of sweet mucilage really appreciated by some animals such as parrots, or even by humans. This palm has flowers and fruits in different months of the year, depending on the region where it is located. Internally, it has a small kernel which is very similar to that of coconut. The leaves are shaped evergreen and are used as cattle feed. The jerivá also provides palm heart for human consumption (LORENZI, 2004).

\subsection{MACAÚBA PALM (Acrocomia aculeata)}

The macaúba is a common species of palm tree found from Pará to São Paulo and Mato Grosso do Sul (Brazil), and has multiple common names, among them bocaiuva, macabira, mocajuba and macaiba. The fruits, consisting of an oleaginous kernel and pulp are found mature from September to December. It presents an edible kernel that can be consumed fresh or as sweet, in the form of crushed peanut candy and coconut candy. From kernels, it is also possible to obtain clear and colorless oil, used in cooking instead of olive oil. The pulp can also be eaten fresh, cooked, in ice creams or in recipes such as biscuits and cakes (ROLIM, 1981).

The macaúba shows great potential for oil production with wide application in industrial and energy sectors, with advantages over other oilseed crops, mainly due to its most profitable agricultural production and total oil (ROLIM, 1981).

Hiane et al. (2005) analyzed the fatty acid profile of oil from the fresh pulp, kernel and flour obtained from the macaúba. According to the study, the oil from fresh pulp and flour had high content of unsaturated fatty acids, predominantly oleic acid. The kernel oil showed mainly oleic, lauric and palmitic acid. A previous study by Oliveira et al. (2006) showed that the macaúba palm fruit is rich in minerals, presenting in its composition $1.725 \mathrm{mg} / 100 \mathrm{~g}$ of potassium, $680 \mathrm{mg} / 100 \mathrm{~g}$ calcium, $2 \mathrm{mg} / 100 \mathrm{~g}$ of manganese, $10.1 \mathrm{mg} / 100 \mathrm{~g}$ iron and $1.5 \mathrm{mg} / 100 \mathrm{~g}$ of zinc.

\section{CONCLUSION}

Many species of tropical palms present as promising sources of bioactive compounds such as phenolics, carotenoids and tocopherols, and contain significant amounts of essential fatty acids. Regular consumption of these substances is beneficial to health as evidenced by several epidemiological studies. For this reason, it becomes important to study the fruit characterization and composition of the oil from palm species of different regions that are still poorly investigated, seeking the possibility of its application in industry or the development of functional foods. 


\section{RESUMO}

\section{COMPOSTOS FENÓLICOS, CAROTENOIDES, TOCOFERÓIS E ÁCIDOS GRAXOS PRESENTES EM ÓLEOS EXTRAÍDOS DE FRUTOS DE PALMEIRAS}

Esta revisão teve como objetivo discutir os principais compostos bioativos presentes em óleos extraídos de palmeiras ainda pouco estudadas, indicando suas possíveis aplicações. Foram abordados os alimentos funcionais, os compostos com atividade antioxidante, como compostos fenólicos, carotenoides, tocoferóis, bem como os ácidos graxos mono e poliinsaturados. Cada vez mais cresce a busca por alimentos, principalmente de origem vegetal, que se caracterizam pela presença de tais substâncias benéficas ao organismo. Muitas pesquisas apontam espécies de palmeiras como importantes fontes de compostos bioativos e de ácidos graxos essenciais, tornando importante sua caracterização e o estudo da composição do óleo de espécies de palmeiras de diferentes regiões que ainda são pouco investigadas, visando sua aplicação pelas indústrias ou para o desenvolvimento de alimentos funcionais.

PALAVRAS-CHAVE: ÁCIDOS GRAXOS; CAROTENOIDES; COMPOSTOS FENÓLICOS; PALMEIRAS; TOCOFERÓIS.

\section{REFERENCES}

1 AHERNE, S.A.; O'BRIEN, N.M. Dietary flavonols: chemistry, food content, and, metabolism. Nutrition, New York, v.18, n.1, p.75-81, 2002.

2 ALMEIDA, N. M. et al. Tocoferóis do músculo dorsal e cavidade ocular do matrinxã (Brycon cephalus) proveniente da Bacia Amazônica em diferentes épocas sazonais. Ciência Rural, Santa Maria, v.36, n.2, p. 636-640, 2006.

3 AMBRÓSIO, C.L.B.; CAMPOS, F.A.C.S.; FARO, Z. P. Carotenóides como alternativa contra a hipovitaminose A. Revista de Nutrição, Campinas, v.19, n.2, p.233-243, 2006.

4 ANDERSON, D. Antioxidant defences against reactive oxygen species causing genetic and other damange. Mutation Research, Amsterdam, v.350, n.1, p.103-108, 1996.

5 ANDRADE, J. S.; PANTOJA, L.; MAEDA, R. N. Melhoria do rendimento e do processo de obtenção da bebida alcoólica de pupunha (Bactris gasipaes Kunth). Ciência e Tecnologia de Alimentos, Campinas, v.23, p.34-38, 2003.

6 American Heart Association (AHA). Scientific Statement: summary of the scientific conference on dietary fatty acids and cardiovascular health. Conference summary from the nutrition committee of The American Heart Association. Circulation, Baltimore, v.103, n.7, p.1034-1039, 2001

7 ANTOLOVICH, M.; PRENZLER, K.R.; RYAN, D. Sample preparation in the determination of phenolic compounds in fruits. Analyst, London, v. 125, n. 5, p. 989-1009, 2000.

8 AZEVEDO-MELEIRO, C.H.; RODRIGUEZ-AMAYA, D.B. Carotenoid composition of kale as influenced by maturity, season and minimal processing. Journal of the Science of Food and Agriculture, London, v. 85, n. 4, p. 591-597, 2005.

9 BARREIROS, A.L.B.S.; DAVID, J.M.; DAVID, J.P. Estresse oxidativo: relação entre geração de espécies reativas e defesa do organismo. Química Nova, São Paulo, v.29, n.1, p.113-123, 2006.

10 BIGLARI, F.; ALKARKHI, A.F.M.; EASA, A.M. Antioxidant activity and phenolic content of various date palm (Phoenix dactylifera) Fruits from Iran. Food Chemistry, London, v.107, n.4, p.1636-1641, 2008.

11 BOBBIO, F.O. et al. Identificação e quantificação das antocianinas do fruto do açaizeiro (Euterpe oleracea) Mart. Ciência e Tecnologia de Alimentos, Campinas, v.20, n.3, p.388-390, 2000

12 BORA, P.S. et al. Characterization of principal nutritional components of Brazilian oil palm (Eliaes guineensis) fruits. Bioresource Technology, Fayetteville, v.87, n.1, p.1-5, 2003.

13 BORA, P.S.; MOREIRA, R.V R. Catolé palm (Syagrus oleracea Mart) fruits: fatty and amino acids composition. Grasas y Aceites, Sevilla, v.54, n.2, p.145-150, 2003.

14 BOVI, M.L.A.; TONET, R.M.; PELINSON, G.J. Palmito gariroba (Syagrus oleracea). Comunicado técnico n. 2. 2000. Available at: http://www.cati.sp.gov.br/produtos/cecor/palgariroba.html Accessed: April 8, 2012.

15 BRANDÃO, S.C.C. Novas gerações de produtos lácteos funcionais. Revista Laticínios, São Paulo, v.6, n.37, p.64-66, 2002.

16 CAMPOS, F.M.; ROSADO, G.P. New conversion factors of provitamin A carotenoids. Ciência e Tecnologia de Alimentos, Campinas, v. 25, n. 3, p. 571-578, 2005. 
17 CARNEIRO, C.E.A.; ROLIM, H.V.M.; FERNANDES, K.F. Procedimento eficiente na inibição do escurecimento de guariroba (Syagrus oleracea, Becc) durante processamento e armazenamento. Acta Scientiarum. Agronomy, Maringá, v. 25 , n. 2, p. 253-258, 2003.

18 CARTER, J.F. Potential of flaxseed and flaxseed oil in baked goods and other products in human nutrition. Cereal Foods World, St. Paul, v. 38, n. 10, p. 753-59, 1993.

19 CASAGRANDE, M.C.R.; KIMURA, M. Carotenoid composition of melon. In: WORLD CONGRESS OF FOOD SCIENCE AND TECHNOLOGY-IUFOST, 13., 2006, Nantes. Proceedings...Nantes: IUFOST, 2006. p. 1791-1792.

20 Chemyunion Química Ltda. Ativos tropicais com eficiência comprovada. Sorocaba, 2002. Available at: http://www. chemyunion.com.br. Accessed: August 23, 2012.

21 CLEMENT, C.R.; LLERAS, P.E.; VAN-LEEUWEN, J. O potencial das palmeiras tropicais no Brasil: acertos e fracassos das últimas décadas. Agrociências, Montevideu, v. 9, n. 1-2, p. 67-71, 2005.

22 CONNOR, W.E. Importance of n-3 fatty acids in health and disease. American Journal of Clinical Nutrition, New York, v. 71 , n. 1 , p. $171 \mathrm{~s}-175 \mathrm{~s}, 2000$.

23 DONATTI, C.I. Conseqüências da defaunação na dispersão de sementes e no recrutamento de plântulas da palmeira brejaúva (Astrocarium aculeatissimum) na Mata Atlântica. 2004. 102 f. Dissertação (Mestrado em Ecologia de Agroecossistemas), Escola Superior de Agricultura Luiz de Queiroz, Universidade de São Paulo, Piracicaba, 2004.

24 FORD, E.S. et al. The metabolic syndrome and antioxidant concentrations: findings from the third national health and nutrition examination survey. Diabetes, New York, v. 52, n. 9, p. 2346-2352, 2003.

25 GODOY, H.T.; RODRIGUES-AMAYA, D.B. Buriti (Mauritia vinifera Mart), uma fonte riquíssima de pró-vitamina A. Arquivos de Biologia e Tecnologia, Curitiba, v. 38, n. 1, p. 109-120, 1995.

27 HALLIWELL, B. Free radicals and antioxidants: a personal view. Nutrition Reviews, New York, v. 52, n. 8, p. 253-265, 1994.

28 HEINONEN, O.P. et al. Prostate cancer and supplementation with alpha-tocopherol and beta-carotene: incidence and mortality in controlled trial. Journal of the National Cancer Institute, Bethesda, v. 90, n. 6, p. 440-446, 1998.

29 HIANE, P.A. et al. Carotenóides pró-vitamínicos A e composição em ácidos graxos do fruto e da farinha do bacuri (Scheelea phalerata Mart.). Ciência e Tecnologia de Alimentos, Campinas, v. 23, n. 2, p. 206-209, 2003.

30 HIANE, P.A. et al. Bocaiúva, Acrocomia Aculeata (Jacq.) Lodd., pulp and kernel oils: characterization and fatty acid composition. Brazilian Journal of Food Technology, Campinas, v. 8, n. 3, p. 256-259, 2005.

31 HOPE, P. P.; KRENNRICH, G. Bioavailability and potency of natural-source and all-racemic $\alpha$-tocopherol in the human: a dispute. European Journal of Clinical Nutrition, London, v. 39, n. 5, p. 183-93, 2000.

32 HUI, M.Y. et al. Comparison of protective effects between cultured Cordyceps militari and natural Cordyceps sinensis against oxidative damage. Journal of Agricultural and Food Chemistry, Easton, v. 54, n. 8, p. 3132-3138, 2006.

33 KHOR, H.T.; CHIENG, D.Y.; ONG, K.K. Tocotrienols inhibit HMGCoA reductase activity in the guinea pig. Nutrition Reviews, New York, v. 15, p. 537-44, 1995.

34 KRUGER, C.L.; MANN, S.W. Safety evaluation of functional ingredients. Food and Chemical Toxicology, Elmsford, v. 41, n. 6 , p. $793-805,2003$

35 LIRA, G.M. et al. Fatty acids composition, chemical centesimal composition and caloric value in raw and boiled mollusks with milk coconut in the city of Maceió, Alagoas, Brazil. Revista Brasileira de Ciências Farmacêuticas, São Paulo, v. 40 , n. 4 , p. $529-537,2004$

36 LORENZI, H. Árvores brasileiras: manual de identificação e cultivo de plantas arbóreas nativas do Brasil. 3. ed. Nova Odessa: Instituto Plantarum, 2000.

37 LORENZI, H. Palmeiras brasileiras e exóticas cultivadas. Nova Odessa: Instituto Plantarum, 2004.160 p.

38 MAHAN, L.K.; ESCOTT-STUMP, S. Krause: alimentos, nutrição e dietoterapia. 10. ed. São Paulo: Roca, 2002.1157 p.

39 MALDONADO-ROBLEDO, G. et al. Production of tobacco aroma from lutein. Specific role of the microorganisms involved in the process. Applied Microbiology and Biotechnology, Berlin, v. 62, n.5, p. 484-488, 2003.

40 MELO, E.A.; GUERRA, N.B. Ação antioxidante de compostos fenólicos naturalmente presentes em alimentos. Boletim da Sociedade Brasileira de Ciência e Tecnologia de Alimentos, Campinas, v. 36, n. 1, p. 1-11, 2002.

41 NIIZU, P.Y.; RODRIGUEZ-AMAYA, D.B. New data on the carotenoid composition of raw salad vegetables. Journal of Food Composition and Analisys, San Diego, v. 18, n. 8, p. 739-749, 2005. 
42 OLIVEIRA, M.N. et al. Aspectos tecnológicos de alimentos funcionais contendo probióticos. Revista Brasileira de Ciências Farmacêuticas, São Paulo, v. 38, n. 1, p.1-21, 2002.

43 OLIVEIRA, A.L. et al. Elemental contents in exotic Brazilian tropical fruits evaluated by energy dispersive X-ray fluorescence. Scientia Agrícola, Piracicaba, v. 63, n. 1, p. 82-84, 2006.

44 PEREIRA, B.A.S. Flora nativa. In: DIAS, B.F.F. Alternativas de desenvolvimento dos cerrados: conservação dos recursos naturais renováveis. Brasília: Fundação Pró-Natureza, 1996. p. 53-57.

45 POMPELLA, A. Biochemistry and histochemistry of oxidant stress and lipid peroxidation. International Journal of Vitamin and Nutrition Research, Berbe, v. 67, n. 5, p. 289-297, 1997.

46 PRATES, J.A.M.; MATEUS, C.M.R.P. Componentes com actividade fisiológica dos alimentos de origem animal. Revista Portuguesa de Ciências Veterinárias, Lisboa, v. 97, n. 541, p. 3-12, 2002.

47 RAMOS, M.I. et al. Bocaiuva (Acrocomia aculeata (Jacq.) Lodd) improved vitamin A status in rats. Journal of Agricultural and Food Chemistry, Easton, v. 55, n. 8, p. 3186-90, 2007.

48 RAUHA, J.P. et. al. Antimicrobial effects of finnish plant extracts containing flavonoids and other phenolic compounds. International Journal of Food Microbiology, Amsterdam, v. 56, n. 1, p. 3-12, 2000.

49 ROCK, C.L. et al. Bioavailability of $\beta$-carotene is lower in raw than in processed carrots and spinach in women. Journal of Nutrition, Philadelphia, v. 128, n. 5, p. 913-916, 1998.

50 RODRIGUEZ-AMAYA, D.B. Avanços na pesquisa de carotenóides em alimentos: contribuições de um laboratório brasileiro. Revista do Instituto Adolfo Lutz, São Paulo, v. 63, n. 2, p. 129-138, 2004.

51 RODRIGUEZ-AMAYA, DB.; KIMURA, M.; AMAYA-FARAFAN, J. Fontes brasileiras de carotenóides: tabela brasileira de composição de carotenóides em alimentos. Brasília: MMA/BBF, 2008. 98 p.

52 ROLIM, A.A.B. Óleos vegetais: usos gerais. Informe Agropecuária, Belo Horizonte, v. 7, n. 82, p. $17-22,1981$.

53 SOUZA, P.H.M.; SOUZA NETO, M.H.; MAIA, G.A. Componentes funcionais nos alimentos. Boletim da Sociedade Brasileira de Ciência e Tecnologia de Alimentos, Campinas, v. 37, n. 2, p. 127-135, 2003.

54 STAHL, W.; SIES, H. Antioxidant defence: vitamins E and C and carotenoids. Diabetes, New York, v. 46, n. 2, p. 14-18, 1997

55 TRABER, M.G. Cellular and molecular mechanisms of oxidants and antioxidants. Mineral and Electrolyte Metabolism, Basel, v. 23, n. 3/6, p. 135-139, 1997

56 TROSKO, J.E.; CHANG, C.C. Mechanism of up-regulated gap junctional intercellular communication during chemoprevention and chemotherapy of cancer. Mutation Research, Amsterdam, v. 480/481, p. 219-229, 2001.

57 TURATTI, J.M.; GOMES, R.A.R.; ATHIÉ, I. Lipídeos: aspectos funcionais e novas tendências. Campinas: ITAL, 2002. 78 p.

58 VALLILO, M.I. etal. Composição química das sementes de Archontophoenix alexandrae H. Wendl. \& Drude (ARECACEAE). Revista Árvore, Viçosa, v. 28, n. 5, p. 676-679, 2004.

59 WALZEM, R.L. Functional foods. Trends in Food Science and Technology, Cambridge, v. 15, n. 11, p. 518, 2004.

60 YU, T.W.; ANDERSON, D. Reactive oxygen species-induced DNA damage and its modification: a chemical investigation. Mutation Research, Amsterdam, v. 379, n. 2, p. 201-210, 1997

61 ZHENG, W.; WANG, S.Y. Antioxidant activity and phenolic compounds in selected herbs. Journal of Agricultural and Food Chemistry, Easton, v. 49, n. 11, p. 5165-5170, 20001.

\section{ACKNOWLEDGMENTS}

The authors are grateful for the assistance of the São Paulo Research Foundation (FAPESP) and National Council for Scientific and Technological Development (CNPq). 